\title{
STRAINS OF LENTINULA EDODES SUPPRESS GROWTH OF PHYTOPATHOGENIC FUNGI AND INHIBIT ALAGOAS SEROTYPE OF VESICULAR STOMATITIS VIRUS
}

\author{
Selma H. Sasaki ${ }^{1}$; Rosa E.C. Linhares ${ }^{2}$; Carlos M. Nozawa²; Ricardo Montalván ${ }^{3}$; Luzia D. Paccola-Meirelles ${ }^{1 *}$ \\ ${ }^{1}$ Departamento de Biologia Geral, Universidade Estadual de Londrina-UEL, Londrina, PR, Brasil; \\ ${ }^{2}$ Departamento de Patologia Geral, UEL, Londrina, PR, Brasil; \\ ${ }^{3}$ Departamento de Agronomia, UNIOESTE, Marechal Candido Rondom, PR, Brasil
}

Submitted: July 05, 2000; Returned to authors for corrections: August 28, 2000; Approved: February 02, 2001

\begin{abstract}
Four Lentinula edodes strains (Le10, 46, K2, Assai) were assessed for their antagonistic effect on four filamentous fungus species of agricultural importance (Helminthosporium euphorbiae, Helminthosporium sp, Fusarium solani and Phomopsis sojae) and on Alagoas serotype of Vesicular Stomatitis Virus (VSA). The L. edodes strains studied had variable effects on the filamentous fungi and on VSA. The K2 and Le10 strains were antagonistic on the fungi assessed and the 46 and K2 strains were efficient on the Vesicular Stomatitis Virus. The results widened the list of beneficial effects of $L$. edodes on the control and prevention of animal pathogenic virus and filamentous fungi.
\end{abstract}

Key words: Phytopathogenic fungi, shiitake, inhibition, Vesicular Stomatitis Virus (Alagoas)

\section{INTRODUCTION}

Lentinula edodes is an edible mushroom, which has been cultivated in the Asian countries for centuries. Lately its cultivation was extended to several areas of Brazil, and it has been employed in human feeding. It is known as 'hoang-mo' in China while its commercial name in Japan is 'shiitake'(5). The ancients considered it the elixir of life because of its high nutritional content (3). The therapeutic importance of $L$. edodes has been known since the Ming dynasty (1368-1644) from reports that shiitake increased the vigor and energy in humans (6). Several papers in the literature reported the production of substances with therapeutic and medicinal properties (including antibiotic, antiviral, antitumors and antithrombosis) isolated from the fruit body, spores, mycelia and mycelial culture medium of $L$. edodes (7,9,17). L. edodes has shown activity in mice against VSV encephalitis (Vesicular Stomatitis Virus) and Abelson virus with $100 \%$ cure (17). Extracts of the fruiting bodies of L. edodes have been shown to contain also potent inhibitors of plant virus. This purified inhibitor was found to be a basic simple protein without carbohydrate content (8). The purpose of the present study was to examine the possibility of the use of shiitake extracts as a preventive agent against filamentous fungi of agricultural interest and on Vesicular Stomatitis Virus - Alagoas (VSA).

\section{MATERIALS AND METHODS}

\section{Lentinula edodes strains}

Four strains of L. edodes were used, Le10, 46, Assaí and $\mathrm{K} 2$, from the stock of fungi at the State University of Londrina/ PR, Brazil.

\section{Phytopathogenic fungi strains}

The antagonistic effect of $L$. edodes strains was assessed on the filamentous fungi, Helminthosporium euphorbiae, Helminthosporium sp., Fusarium solani and Phomopsis sojae obtained from the stock of fungi of the Phytopathology Laboratory of Embrapa Soya at Londrina/PR, Brazil.

\footnotetext{
* Corresponding author. Mailing address: Universidade Estadual de Londrina, CCB / BIO, Caixa Postal: 6001. CEP 86051-990, Londrina, PR, Brasil. Tel.: (+5543) 371-4439.E-mail: paccola@uel.br
} 


\section{Virus}

Alagoas serotype of Vesicular Stomatitis Virus (VSA) was obtained from the collection of the Department of Microbiology at the State University of Londrina/PR, Brazil.

\section{Extract from $L$. edodes mycelium and culture filtrate}

The $L$. edodes strains were separately grown on potatodextrose-agar medium, at $25^{\circ} \mathrm{C}$ in the dark. An agar disk (10 $\mathrm{mm}$ diameter) bearing mycelium of $L$. edodes was placed in $100 \mathrm{~mL}$ of potato-broth at $25^{\circ} \mathrm{C}$ for 20 days. The cultures were filtered vacuum in a Buchner filter and the filtrate, denominated Culture Filtrate $(\mathrm{CF})$, was sterilized in Millipore membrane $(0.22 \mu)$ and stored at $4^{\circ} \mathrm{C}$ until use. The mycelia were squashed in sterilized distilled water (ratio $0.5 \mathrm{~g}: 4 \mathrm{~mL}$ water) and centrifuged at 3,000 rpm for 10 minutes. The supernatant, denominated Mycelial Extract (ME), was stored at $4^{\circ} \mathrm{C}$.

\section{Assessment of $\boldsymbol{L}$. edodes effect on filamentous fungi}

An agar disc (10mm diameter) bearing mycelium of each phytopathogenic fungi was placed on the surface of PDA medium $(20 \mathrm{~mL})$ (potato dextrose agar- Biobrás) added of 10\%, 20\% and $30 \%$ of CF of L. edodes and incubated at $28^{\circ} \mathrm{C}$ in the dark. After the second day of incubation, daily measurements of the diameter $(\mathrm{mm})$ of colony growth were taken and recorded. The experiments were carried out in quadruplicate. These values were converted into area and corrected by the formula below to compare the treatments:

$$
\mathrm{CV}=1+\frac{\text { FMAC- } \mathrm{IA}}{\text { FMAC- IAC }}
$$

Where:

$\mathrm{CV}=$ Corrected Value;

$\mathrm{IA}=$ Inoculum Area;

FMAC $=$ Final Means Area of the Control;

IAC $=$ Inoculum Area of the Control.

\section{Assessment of $L$. edodes effect on VSA}

Vero cells were cultivated in 96-well tissue culture microplates for $48 \mathrm{~h}$ in medium 199 supplemented with F10 (Sigma) at $37^{\circ} \mathrm{C}$ in $5 \% \mathrm{CO}_{2}$. The culture media were substituted by fresh media containing virus at $10^{-1}$ to $10^{-7}$ dilutions with or without ME and CF from four L. edodes strains. ME and CF dilutions (1:10, 1:20, 1:30, 1:40, and 1:80) were previously tested for cytotoxic effects on cell culture. VSA - infected and noninfected cell cultures treated with $L$. edodes $\mathrm{ME}$ and $\mathrm{CF}$ were maintained for control. The experiments were carried out in triplicate. Cell cultures were daily observated and viral titer (titer capable of infecting $50 \%$ of the cell cultures per $\mathrm{mL}$ - $\mathrm{TCID}_{50} / \mathrm{mL}$ ) was calculated according to Reed and Muench (12). The viral inhibition percentage was calculated as described in Nishimura et al. (10).

\section{RESULTS AND DISCUSSION}

\section{Assessment of $L$. edodes effect on phytopathogenic fungi}

The results showed that L. edodes strains, K2 and Le10, had a greater inhibitory effect on the phytopathogenic fungi than the 46 and Assaí strains (Table 1).

The $0.3 \mathrm{~mL} \mathrm{~L}$. edodes culture filtrate dose had the greatest antagonistic effect on the fungi, regardless the $L$. edodes strain used (Table 2).

The H. euphorbia and Helminthosporium sp fungi were more susceptible to the L. edodes treatment than the other fungi (Table 3).

The filamentous fungi assessed in this work infect mainly the soybean (Glycine max) crops decreasing yield. $H$. euphorbiae, however, is a phytopathogen with great potential

Table 1. Antagonism of four Lentinula edodes strains on phytopathogenic fungi (Phomopsis sojae, Fusarium solani, Helminthosporium sp., Helminthosporium euphorbiae).

\begin{tabular}{cc}
\hline Area means $(\mathrm{mm})^{*}$ & L. edodes strains \\
\hline $17,836 \mathrm{a}$ & Assaí \\
$17,757 \mathrm{a}$ & 46 \\
$15,914 \mathrm{~b}$ & Le10 \\
$14,675 \mathrm{~b}$ & $\mathrm{~K} 2$ \\
\hline
\end{tabular}

* Means represented by the same letter do not differ significantly by the Tukey test $(\mathrm{p}<0.05)$.

Table 2. Effect of different Lentinula edodes culture filtrate doses on the growth of the phytopathogenic fungi.

\begin{tabular}{cc}
\hline Area means $(\mathrm{mm})^{*}$ & Doses \\
\hline $17,390 \mathrm{a}$ & D1 \\
$16,924 \mathrm{a}$ & $\mathrm{D} 2$ \\
$15,323 \mathrm{~b}$ & $\mathrm{D} 3$ \\
\hline
\end{tabular}

* Means represented by the same letter do not differ significantly by the Tukey test $(\mathrm{p}<0.05)$. $\mathrm{D} 1=0.1 \mathrm{~mL}$ L. edodes $\mathrm{CF}$ from PDA medium; $\mathrm{D} 2=0.2 \mathrm{~mL}$ L. edodes $\mathrm{CF}$ from PDA medium; $\mathrm{D} 3=0.3 \mathrm{~mL}$ L. edodes $\mathrm{CF}$ from PDA medium.

Table 3. Effect of the culture filtrate of Lentinula edodes on the growth of the phytopathogenic fungi.

\begin{tabular}{cl}
\hline Area means $(\mathrm{mm})^{*}$ & \multicolumn{1}{c}{ Fungi } \\
\hline $18,496 \mathrm{a}$ & Phomopsis sojae \\
$18,046 \mathrm{a}$ & Fusarium solani \\
$14,501 \mathrm{~b}$ & Helminthosporium sp \\
$11,00 \mathrm{c}$ & Helminthosporium euphorbiae \\
\hline
\end{tabular}

* Means represented by the same letter do not differ significantly by the Tukey test $(\mathrm{p}<0.05)$. 
for use in biological control of the weed Euphorbia heterophpylla, known popularly as Moleplant in soybean crops $(14,15)$. Helminthosporium sp. affects many grasses (wheat, rye, etc.) causing localized lesions and root rotting (4). Fusarium solani causes the red root rot disease and it is a problem in soybean seed production (16). P. sojae is the pathogen that causes the dry or burn stem disease, which is very common in soybean crops (4). These diseases are normally controlled with chemicals and adequate soil management. The use of natural products for the control of these diseases is a promising alternative and has received much attention worldwide.

Pacumbaba et al. (11) determined the inhibitory activity of the mycelial leachate of $L$. edodes on the growth of several important species of plant pathogenic bacteria in the laboratory. The mycelial leachate applied as soil drench prevented symptom expression of soyborn bacterial pathogens, suggesting that the shiitake mycelial leachate contains an antibiotic component.

In the literature, the effect of L. edodes on fungi is described only in the yeast Candida albicans and a compound, denominated Cortinellin, isolated from $L$. edodes showed antibiotic activity against this yeast (1). Therefore, this is the first time that mycelial extract of $L$. edodes has been reported to inhibit the growth of phytopathogenic fungi.

Table 4. Effect of the interaction of the culture filtrate and the mycelial extract of four Lentinula edodes strains in the replication of VSA in Vero cell culture, in $\mathrm{TCID}_{50} / \mathrm{mL}$.

\begin{tabular}{|c|c|c|c|}
\hline L. edodes & Strains* & Treatment** & Control** \\
\hline \multirow[t]{2}{*}{$\mathrm{K} 2$} & $\mathrm{ME}$ & $10^{3,24}$ & $10^{5,24}$ \\
\hline & $\mathrm{CF}$ & $10^{5,24}$ & $10^{5,24}$ \\
\hline \multirow[t]{2}{*}{ Le10 } & $\mathrm{ME}$ & $10^{5,24}$ & $10^{5,24}$ \\
\hline & $\mathrm{CF}$ & $10^{5,24}$ & $10^{5,24}$ \\
\hline \multirow[t]{2}{*}{46} & $\mathrm{ME}$ & $10^{4,24}$ & $10^{5,24}$ \\
\hline & $\mathrm{CF}$ & $10^{3,24}$ & $10^{5,24}$ \\
\hline \multirow[t]{2}{*}{ Assaí } & $\mathrm{ME}$ & $10^{5,24}$ & $10^{5,24}$ \\
\hline & $\mathrm{CF}$ & $10^{5,24}$ & $10^{5,24}$ \\
\hline
\end{tabular}

* ME: Mycelial Extract; CF: Culture Filtrate; ** Viral titer expressed in $\mathrm{TCID}_{50} / \mathrm{mL}$ and calculated according to Reed and Müench (1938).

Table 5. VSA inhibition percentage caused by four Lentinula edodes strains in Vero cell culture.

\begin{tabular}{c|cc}
\hline L. edodes Strains & $\mathrm{ME}^{*}$ & $\mathrm{CF}^{* *}$ \\
\hline $\mathrm{K} 2$ & $99 \%$ & 0 \\
46 & $90 \%$ & $99 \%$ \\
Assaí & 0 & 0 \\
Le10 & 0 & 0 \\
\hline
\end{tabular}

* ME: Mycelial Extract; **CF: Culture Filtrate

\section{L. edodes effect on VSA}

The ME and CF did not have a toxic effect on the Vero cell culture at the 1:20 (Le10 and Assaí strains) or 1:30 dilutions (K2 and 46 strains). Table 4 shows the result of the ME and CF interaction and the cytopathic effect of the virus.

The percentage of viral inhibition was calculated for each L. edodes strain (Table 5) based on viral titer in the presence or absence of $\mathrm{ME}$ and $\mathrm{CF}$.

Only two L. edodes strains were effective in inhibiting VSA replication. Strain 46 was an effective antiviral both with ME and CF. The latter was more efficient with $99 \%$ inhibition. The K2 strain was efficient only with ME, showing an inhibition percentage of $99 \%$.

The VSA causes a disease characterized by the appearance of vesicular lesions in the mouth and hooves of horses but it can also affect swine and cattle. In swine lesions may lead to the loss of the hoof. Mouth lesions (which are the most important) are not usually treated because they heal naturally within a week. The disease causes weight loss in cattle because of the temporary inability to eat, and a decrease in milk production of around $20 \%$, which returns to $70-80 \%$ of the normal production within a month. The symptoms of this infection are very similar to foot and mouth fever and the swine vesicular disease and thus deserve attention (2).

Tsunoda and Ishida (13) described indirect $L$. edodes antiviral activity in watery extract from the fruit body and spores. As described in the present study, the authors observed that the extract from the shiitake fruit body contains potent plant virus inhibitors. Kobayashi et al. (8) also described a substance from the L. edodes fruit body that had inhibitory action on the plant virus infection. This substance was described as being a protein. Various substances from the mycelia and $L$. edodes fruit body have already been reported as having antiviral activities in plants. Tests of these substances used as an antiviral have been made for the inhibition of viral infection in plants (8).

The present results widen the list of beneficial effects of $L$. edodes and suggest the possibility of using this basidiomycete in the control and prevention of other animal viral and fungal infections of agronomic and veterinary interest. But the data also showed a variability among the strains studied for the assessed traits were, not all the strains had an inhibitory effect on the VSA virus and on the fungi. So, the generalization of the antifungal and antiviral effect for the L. edodes species as a whole should be made with caution.

\section{ACKNOWLEDGMENTS}

The authors thank Dr. Léo Pires Ferreira and Dr. José Tadashi Yorinori from Embrapa Soybean in Londrina, PR, for supplying the fungi. Thanks are also due to CAPES for financial support. 


\section{RESUMO}

\section{Linhagens de Lentinula edodes inibem fungos fitopatogênicos e o vírus da estomatite vesicular, sorotipo Alagoas}

Quatro linhagens de Lentinula edodes (Le10, 46, K2, ASSAI) foram avaliadas quanto ao seu efeito inibitório sobre quatro espécies de fungos filamentosos de importância agrícola (Helminthosporium euphorbiae, Helminthosporium sp., Fusarium solani, Phomopsis sojae) e sobre o sorotipo Alagoas vírus da estomatite vesicular (VSA). Foi observado que as linhagens de $L$. edodes estudadas apresentaram variabilidade quanto ao seu efeito, tanto sobre os fungos filamentosos quanto sobre o vírus VSA. As linhagens K2 e Le10 apresentaram-se antagônicas sobre os fungos e as linhagens 46 e K2 foram eficientes na inibição do vírus VSA. Os resultados obtidos permitem ampliar a lista de efeitos benéficos de algumas linhagens de $L$. edodes no controle e prevenção de vírus patogênicos animais e de fungos filamentosos.

Palavras-chave: Fungos fitopatogênicos, shiitake, inibição, vírus VSA

\section{REFERENCES}

1. Bianco, C. Basideomycetes in relation to antibiosis. II. Antibiotic activity of mycelia and culture liquids. Bact. Viral Immun., 75: 627-274, 1981.

2. Wagner, R.R. Rhabdoviridae and their replication. In: B.N. Fields et al. (eds.), Virology, 2nd ed. Raven Press, New York, 1990, p.867-881.
3. Crisan, E.V.; Sands, A. Nutritional value. In: Chang, S.T.; Hayes, W.A. (eds) The biology and cultivation of edible mushrooms. Academic Press, London, 1978, p.137-165.

4. Galli, F. Manual de Fitopatologia. Agronômica Ceres, São Paulo, 1980, v. $2,587 \mathrm{p}$.

5. Herrera, T.; Ulloa, M. El reino de los hongos: micología básica y aplicada. Univ. Autónoma de México, Fondo de Cultura Económica, México, 1990, 552p.

6. Ito, T. Cultivation of Lentinus edodes. In: Chang, S.T.; Hayes, W.A. (eds) The biology and cultivation of edible mushrooms. London: Academic Press, 1978, p.461-473.

7. Jong, S.C.; Birmingham, J.M. Medicinal and therapeutic value of the shiitake mushroom. Appl. Microbiol., 39: 153-184, 1993.

8. Kobayashi, N.; Hiramatsu, A.; Akasuka, T. Purification and chemical properties of an inhibitor of plants virus infection from fruiting bodies of Lentinus edodes. Agric. Biol. Chem., 51: 883-890, 1987.

9. Mizuno, T. Shiitake, Lentinus edodes: functional properties for medicinal and food purposes. F. Ver. Intern., 11: 111-128, 1995.

10. Nishimura, T.; Toku, H.; Fukuyaser, H. Antiviral compounds. XII Antiviral activity of alkoxyphenil-substitute of carboamil compounds against influenza virus in eggs and in mice. Kitasato Arch. Exp. Med., 50: 39-46, 1977.

11. Pacumbaba, R.P.; Beuel, C.A.; Pacumbaba, R.O. Jr. Shiitake mycelial leachate suppress growth of some bacterial wilt of tomato and lima bean in vitro. Plant Dis., 83: 20-23, 1999.

12. Reed, L.J.; Muench, H. A simple method of estimating fifty percent endpoints. Am. J. Hyg., 27: 493-497, 1938.

13. Tsunoda, A. Ishida, N. A mushroom extract as an interferon inducer. Ann N.Y. Acad. Sci. 173: 719-726, 1969.

14. Yorinori, J.T.; Gazziero, D.L.P. Control of milk weed (Euphorbia heterophylla) with Helminthosporium sp. International Symposium Biological Control of Weeds, 7 Rome, 1988. Proceedings. Institute Sperimentale per la Patologia Vegetale/MAF, 1989 p.571-576

15. Yorinori, J.T. Controle biológico de ervas daninhas com microrganismos. Reunião Anual Sobre Controle Biológico de Plantas, Piracicaba, 1987. p.20-30.

16. Yorinori, J.T. Podridão vermelha da raiz, uma séria doença da soja e do feijão, causada por Fusarium solani. Fitopatol. Bras. 19: 333, 1994 (summary).

17. Wasser, S.P.; Weis, A.L. Therapeutic effects of substances occurring in higher basidiomycetes mushrooms: A modern perspective. Crit. Rev. Immun., 19: 65-96, 1999. 